\section{Use of Reduced Irrigation Operating Pressure in Irrigation Scheduling. II. Effect of Reduced Irrigation System Operating Pressure on Drip- tape Flow Rate, Water Application Uniformity, and Soil Wetting Pattern on a Sandy Soil}

\author{
Bee Ling Poh ${ }^{1,4}$, Aparna Gazula ${ }^{2}$, Eric H. Simonne ${ }^{1}$, \\ Robert C. Hochmuth ${ }^{3}$, and Michael R. Alligood ${ }^{1}$
}

ADDITIONAL INDEX WORDs. hourly evapotranspiration, emitter, dye test

SUMMARY. For shallow-rooted vegetables grown in sandy soils with low waterholding capacity (volumetric water content $<10 \%$ ), irrigation water application rate needs to provide sufficient water to meet plant needs, to avoid water movement below the root zone, and to reduce leaching risk. Because most current drip tapes have flow rates (FRs) greater than soil hydraulic conductivity, reducing irrigation operating pressure (OP) as a means to reduce drip emitter FR may allow management of irrigation water application rate. The objectives of this study were to determine the effect of using a reduced system OP (6 and $12 \mathrm{psi}$ ) on the FRs, uniformity, and soil wetted depth and width by using three commercially available drip tapes differing in emitter FR at 12 psi (Tape $A=0.19 \mathrm{gal} / \mathrm{h}$, Tape $B=0.22$ $\mathrm{gal} / \mathrm{h}$, and Tape $\mathrm{C}=0.25 \mathrm{gal} / \mathrm{h}$ ). Reducing $O P$ reduced FRs (Tape $A=0.13 \mathrm{gal} / \mathrm{h}$, Tape $B=0.17 \mathrm{gal} / \mathrm{h}$, and Tape $\mathrm{C}=0.16 \mathrm{gal} / \mathrm{h}$ ) without affecting uniformity of irrigation at 100 and $300 \mathrm{ft}$ lateral runs. Flow rate was also reduced at $300-\mathrm{ft}$ lateral length compared with $100 \mathrm{ft}$ for all three tapes. Uniformity was reduced ["moderate" to "unacceptable" emitter flow variation $\left(q_{\mathrm{var}}\right)$ and "moderate" coefficient of variation (CV)] at $300 \mathrm{ft}$ for Tape B and C compared with "good" qvar and "moderate" to "excellent" $\mathrm{CV}$ at $100 \mathrm{ft}$. Using soluble dye as a tracer, depth $(D)$ of the waterfront response to irrigated volume $(V)$ was quadratic, $D=4.42+0.21 V-$ $0.001 V^{2}\left(P<0.01, R^{2}=0.72\right)$, at 6 psi, with a similar response at 12 psi, suggesting that depth of the wetted zone was more affected by total volume applied rather than by OP itself. The depth of the wetted zone went below 12 inches when $V$ was $\approx \mathbf{4 5}$ gal $/ 100 \mathrm{ft}$, which represented $\approx 3 \mathrm{~h}$ of irrigation at $6 \mathrm{psi}$ and $1.8 \mathrm{~h}$ of irrigation at $12 \mathrm{psi}$ for a typical drip tape with FR of $0.24 \mathrm{gal} / \mathrm{h}$ at $12 \mathrm{psi}$. These results show that, for the same volume of water applied, reduced OP allowed extended irrigation time without increasing the wetted depth. OP also did not affect the width $(W)$ of the wetted front, which was quadratic, $W=6.97+0.25 \mathrm{~V}-0.002 \mathrm{~V}^{2}\left(P<0.01, R^{2}=\right.$ 0.70 ), at 6 psi. As the maximum wetted width at reduced OP was $53 \%$ of the 28-inch-wide bed, reduced OP should be used for two-row planting or drip-injected fumigation only if two drip tapes were used to ensure good coverage and uniform application. Reducing OP offers growers a simple method to reduce FR and apply water at rates that match more closely the hourly evapotranspiration, minimizing the risk of leaching losses.

I n Florida, irrigation scheduling is becoming more important in vegetable production as a result of increasing restriction on use of water resources (Dukes et al., 2010) and the need to improve fertilizer use efficiency (Obreza and Sartain, 2010).

${ }^{1}$ Horticultural Sciences Department, University of Florida, 1238 Fifield Hall, PO Box 110690, Gainesville, FL 32611-0690

${ }^{2}$ Alachua County Extension Office, $2800 \mathrm{NE} 39$ th Avenue, Gainesville, FL 32609-2658

${ }^{3}$ North Florida Research and Education CenterSuwannee Valley, 7580 County Road 136, Live Oak, FL 32060

${ }^{4}$ Corresponding author. E-mail: pohbeeling@ufl.edu.
Current best management practices and University of Florida's Institute of Food and Agricultural Sciences (UF/IFAS) recommendations specify the amount to irrigate, adjusting it on the basis of soil moisture, accounting for rainfall contribution, and splitting irrigation events that are greater than $2 \mathrm{~h}$ (Florida Department of Agriculture and Consumer Services, 2005; Simonne et al., 2010).

An irrigation event should be able to provide water to wet the root zone for active uptake of water. In two studies conducted on tomato (Solanum lycopersicon), roots were localized in the top 12-16 inches of the soil, with $\approx 90 \%$ of them found laterally within 8 inches of the stem (Hammami and Daghari, 2007; Machado et al., 2003). Assuming a fully expanded active crop root zone of 8 -inch radius and 12-inch depth that occupies a cylindrical soil volume, the greatest volume of water that could be stored in Florida's sandy soils with poor water-holding capacity of $0.03-0.10$ inch of water per inch of soil is $0.3-1.0$ gal for each plant root system (U.S. Department of Agriculture, 2006). For drip-irrigated tomatoes on 6 -ft bed centers grown with plastic mulch on Florida's sandy soils, the estimated daily crop water use [evapotranspiration (ETc)] could be as high as $4600 \mathrm{gal} / \mathrm{acre}$ or $63 \mathrm{gal} /$ $100 \mathrm{ft}(0.95 \mathrm{gal} / \mathrm{plant}$ per day for 4840 plants at 18 -inch plant spacing) (Simonne et al., 2010). Currently, available low-to-medium flow drip tapes typically range between 15 and $24 \mathrm{gal} / 100 \mathrm{ft}$ per hour. More commonly, the FR of $24 \mathrm{gal} / 100 \mathrm{ft}$ per hour is used for tomato production, with nearly $2.5 \mathrm{~h}$ of irrigation needed to meet daily plant water demand of $63 \mathrm{gal} / 100 \mathrm{ft}$. Irrigating continuously for $2.5 \mathrm{~h}$ to supply 0.95 $\mathrm{gal} / \mathrm{plant}$ of water would be at the upper end of storable water for this volume of soil $(0.3-1.0 \mathrm{gal})$, thereby increasing the risk of deep percolation of water. Hence, UF/IFAS recommends that such irrigation be split into three irrigations of $\approx 1500 \mathrm{gal} / \mathrm{acre}$ $(0.31 \mathrm{gal} /$ plant $)$ each to replace ETc

\begin{tabular}{llll}
\hline $\begin{array}{l}\text { Units } \\
\begin{array}{l}\text { To convert U.S. to SI, } \\
\text { multiply by }\end{array}\end{array}$ & U.S. unit & SI unit & $\begin{array}{l}\text { To convert SI to U.S., } \\
\text { multiply by }\end{array}$ \\
\hline 0.3048 & $\mathrm{ft}$ & $\mathrm{m}$ & 3.2808 \\
3.7854 & $\mathrm{gal}$ & $\mathrm{L}$ & 0.2642 \\
0.1242 & gal/100 $\mathrm{ft}$ & $\mathrm{L} \cdot \mathrm{m}^{-1}$ & 8.0520 \\
9.3540 & gal $/ \mathrm{acre}$ & $\mathrm{L} \cdot \mathrm{ha}^{-1}$ & 0.1069 \\
2.54 & inch $(\mathrm{es})$ & $\mathrm{cm}$ & 0.3937 \\
62.7648 & inch $(\mathrm{es}) / \mathrm{acre}$ & $\mathrm{mm} \cdot \mathrm{ha}^{-1}$ & 0.0159 \\
1 & ppm & $\mathrm{mg} \cdot \mathrm{L}^{-1}$ & 1 \\
6.8948 & psi & $\mathrm{kPa}$ & 0.1450
\end{tabular}


and not to exceed soil's water-holding capacity (Fig. 1A). However, recent research (Farneselli et al., 2008; Simonne et al., 2003, 2006a) has indicated that although UF/IFAS recommendations satisfy plant water needs, they may not be sufficient to keep the wetted front from moving below the typical vegetable active root zone of 12 inches.
Shallow $(20 \mathrm{ft})$ water quality monitoring has also found nitrate- $\mathrm{N}\left(\mathrm{NO}_{3}{ }^{-}-\mathrm{N}\right)$ concentrations to spike up to 40 $\mathrm{mg} \cdot \mathrm{L}^{-1} \cdot \mathrm{NO}_{3}{ }^{-}-\mathrm{N}$ when these recommendations are followed (Simonne et al., 2006b). It may be possible to further reduce the risk of deep percolation if reduced amounts of water were applied during the different
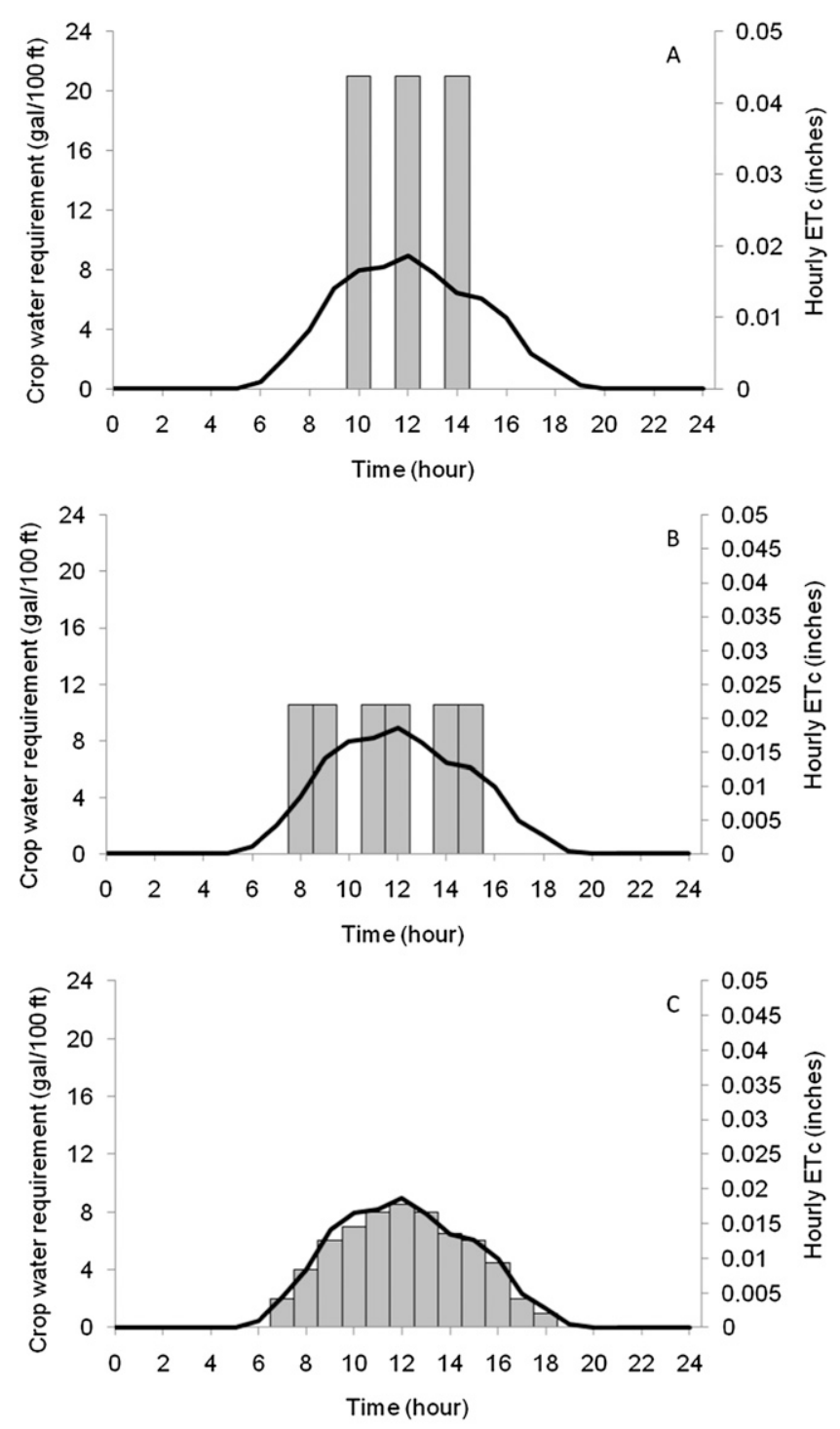

$\sqsubseteq$ Irrigated water $\longrightarrow$ Crop water requirement

Fig. 1. Changes in hourly crop water requirement and crop evapotranspiration (ETc) within a 24-h period for open-field production of drip-irrigated tomato in central Florida showing (A) current recommended bulk water application through split-irrigation scheduling $(3 \times 1$-h gray bars $),(B)$ proposed modified extended irrigation with reduced operating pressure irrigation system, and (C) ideal continuous irrigation at flow rates that match hourly ETc. Hourly crop water requirement and ETc were estimated based on a reference evapotranspiration of 0.18 inches/acre $\left(11.298 \mathrm{~mm} \cdot \mathrm{ha}^{-1}\right)$ [or $4887 \mathrm{gal} /$ acre $\left(45.7 \mathrm{~m}^{3} \cdot \mathrm{ha}^{-1}\right)$ per day] (Simonne et al., 2010) and diurnal fluctuation in solar radiation in June (University of Florida, 2010). Note: for A, B, and C, the total daily water application (total gray surface) is constant. Water application rate above ETc (gray bar above the curve) represents the risk of deep water percolation and loss. $1 \mathrm{gal} / 100 \mathrm{ft}=0.1242 \mathrm{~L} \cdot \mathrm{m}^{-1}$; 1 inch $=2.54 \mathrm{~cm}$.

irrigation cycles within a day (Fig. 1B). Current crop water use estimates are based on daily ETc estimates. ETc varies according to the diurnal flux of solar radiation (Zur and Jones, 1981), and $30 \%$ to $40 \%$ of daily ET may occur during the 2 -h period between 11:00 AM and 1:00 PM (Clark and Smajstrla, 1996). The crop water need during this period is $\approx 0.4 \mathrm{gal} / \mathrm{plant}$ with an hourly requirement of 0.2 gal/plant. Current UF/IFAS recommendations do not take into account the variation in hourly ETc (ETch). The risk of water draining below the crop root zone could be reduced if drip irrigation provides slow but continuous irrigation that matches more closely ETch (Fig. 1C). This would require a variable FR that could be changed by changing operating pressure (OP).

Water can be applied slowly (Fig. $\mathrm{IB}$ and $\mathrm{C}$ ) by using emitters with low FRs (<15 gal $/ 100 \mathrm{ft}$ per hour). Studies had found that more water was retained in the upper soil level when a lower emitter FR was used. Levin et al. (1979) observed higher soil moisture content and greater water retention in the $0-60 \mathrm{~cm}$ depth of a sandy soil at a lower FR of $1 \mathrm{~L} \cdot \mathrm{h}^{-1}$ compared with higher FRs of 2, 4, and $8 \mathrm{~L} \cdot \mathrm{h}^{-1}$. Bar-Yosef and Sheikolslami (1976) also found that in a Nezarim sandy soil, vertical movement was greater at higher emitter FR of $2.5 \mathrm{~L} \cdot \mathrm{h}^{-1}$, with the waterfront moving to more than $30 \mathrm{~cm}$ in depth and $15 \mathrm{~cm}$ sideways compared with the lower FR of 0.25 $\mathrm{L} \cdot \mathrm{h}^{-1}$ in which the depth was $<20 \mathrm{~cm}$ and width was $19 \mathrm{~cm}$. On the other hand, other reports had contradictory findings in which greater downward water movement was observed in a sandy soil at a lower FR of $2 \mathrm{~L} \cdot \mathrm{h}^{-1}$ compared with 4 and $8 \mathrm{~L} \cdot \mathrm{h}^{-1}$ (Badr and Taalab, 2007). Similarly, Mmolawa and Or (2000) modeled a greater downward movement of water and solutes in a Nahal Sinai sandy soil when the discharge rate was $4 \mathrm{~L} \cdot \mathrm{h}^{-1}$ compared with $20 \mathrm{~L} \cdot \mathrm{h}^{-1}$. Limited information existed about the use of low emitter FR on Florida's sandy soils, and it is not clear if lower emitter FR would result in decreased or increased downward movement of water.

Drip tapes with FRs less than 15 gal/100 ft per hour are usually not widely available. Lower FRs could be created by reducing OP of irrigation 
system because emitter FR is empirically related to water pressure by

$$
q=k p^{x}
$$

where $q$ is the emitter $\mathrm{FR}(\mathrm{gal} / \mathrm{h})$, $p$ is the water pressure (psi), $k$ is the emitter discharge coefficient, and $x$ is the emitter discharge exponent (Smajstrla et al., 2008; Thompson, 2003). The exponent $x$ is unique for each type of drip tape as it varies with the types of emitter and plastic used. For laminar flow where FR varies directly with pressure, $x$ approaches 1 . For turbulent orifice flow, $x$ is 0.5 , whereas for fully pressure-compensating emitter, $x$ is close to 0.1 (Thompson, 2003). Manufacturers typically do not report $k$ and $x$ values on the drip tape label. Instead, they guaranteed uniformity at a maximum lateral length, FR, and OP.

Dowgert et al. (2007) suggested the use of gravity-based systems operating on very low pressures of 3-5 psi, resulting in lower FRs that allowed greater lateral soil water movement in addition to reducing deep percolation and, hence, losses of water and crop nutrients. At the low pressure of 3 psi, they obtained measured FRs that match calculated rates based on $k$ and $x$ values and good emission uniformity $(>90 \%)$ for lateral lengths of $240 \mathrm{ft}$. Using a pressure of $3 \mathrm{psi}$, they applied 2 inches of water in $36 \mathrm{~h}$ to achieve uniform whole bed soil wetting for onion (Allium cepa) establishment in Texas, whereas the same water amount was applied in $3 \mathrm{~h}$ at standard 10 psi pressure and soil wetting of the bed was not complete. Furthermore, with the lower rate of water application, they reported water savings of $40 \%$ to $60 \%$ for potato (Solanum tuberosum) and corn (Zea mays), respectively, grown in Chihuahua, Mexico. We hypothesized that the reduced OP could also be applied in conventional drip irrigation systems to create lower FRs that would apply water slowly and continuously so that hourly water needs of plant are met while minimizing losses from deep percolation. However, it is possible that reduced OP may reduce uniformity, which may result in uneven plant growth. The objectives of this study were to determine the effect of using a reduced system OP on the FRs, uniformity on 100- and 300-ft-long laterals, and soil wetted depth and width using three commercially available drip tapes.

\section{Materials and methods}

FlOW RATES AND UNIFORMITY TRIALS. An experiment was conducted twice at the North Florida Research and Education Center-Suwannee Valley near Live Oak, FL, in Fall 2009. The irrigation system consisted of a well, a pump, a back-flow prevention device, a 150-mesh screen filter, in-line pressure regulators of 6 and 12 psi, and drip tape. Drip tape was laid flat on top of the ground without raised bed. Pins were used about every $50 \mathrm{ft}$ to keep the drip tapes straight and in place. Operating pressure was regulated by installing in-line pressure regulators (Senninger Irrigation, Orlando, FL) for the standard OP of 12 psi, $2-20 \mathrm{gal} / \mathrm{min}$, and reduced OP of $6 \mathrm{psi}, 4-16 \mathrm{gal} / \mathrm{min}$. Three drip tapes with 12 -inch emitter spacing were tested [Eurodrip, $0.16 \mathrm{gal} / \mathrm{h}$ at $10 \mathrm{psi}$ (Eurodrip U.S.A., Madera, CA); Typhoon, $0.24 \mathrm{gal} / \mathrm{h}$ at $10 \mathrm{psi}$ (Netafim U.S.A., Fresno, CA); and Ro-Drip, $0.24 \mathrm{gal} / \mathrm{h}$ at $8 \mathrm{psi}$ (John Deere Water, San Marcos, CA)] at 12 and 6 psi OP and on 100 and $300 \mathrm{ft}$ length laterals. The three drip tapes were designated Tapes A, B, and C.

Manufacturers' recommendations for maximum drip tape run lengths range from 300 to $1000 \mathrm{ft}$. The lowend $300 \mathrm{ft}$ was chosen as the standard in comparison with a shorter length of $100 \mathrm{ft}$. After pressurizing the system, water from two consecutive emitters was collected using a catch can for $10 \mathrm{~min}$ at every $50 \mathrm{ft}$ interval along each drip tape. There were three (at 0,50 , and $100 \mathrm{ft}$ ) and seven (at 0 , $50,100,150,200,250$, and $300 \mathrm{ft}$ ) sampling points for the 100 - and 300 -ft lengths, respectively. Flow rate for each drip tape at each length was calculated as the mean emitter discharge of the three to seven sampling points. Uniformity of water application was assessed according to Camp et al. (1997). Briefly, emitter flow variation $\left(q_{\mathrm{var}}\right), \mathrm{Cv}$, and uniformity coefficient (UC) were calculated as follows:

$$
q_{\mathrm{var}}=100\left(\frac{q_{\max }-q_{\min }}{q_{\max }}\right),
$$

where $q_{\max }$ is the maximum emitter FR and $q_{\text {min }}$ is the minimum emitter FR.

$$
\mathrm{CV}=100\left(\frac{s}{\bar{q}}\right),
$$

where $s$ represents the SD of emitter FRs and $\bar{q}$ is the mean emitter FR.

$$
\mathrm{UC}=100\left[1-\frac{\frac{1}{n} \sum_{i=1}^{n}\left|q_{i}-\bar{q}\right|}{\bar{q}}\right],
$$

where $n$ represents the number of emitters evaluated and $q_{\mathrm{i}}$ is the emitter FR of the $i$ th emitter. The 12 treatments ( 3 drip tapes $\times 2$ OP $\times$ 2 lateral lengths) were replicated four times in a split-split-plot randomized complete block design, with OP as main plot factor, drip tape as subplot, and length as sub-sub-plot. SAS Proc Mixed (version 9.2; SAS Institute, Cary, NC) was used for analysis of variance of the FRs, $q_{\mathrm{var}}, \mathrm{CV}$, and UC in different drip tape types, length, and OP treatments.

Dye TESTS TO VISUALIZE WETTED zONES. Another experiment was repeated at the same location on an Alpin-Blanton-Foxworth fine sand in Fall 2008 and 2009 using new rolls of tapes each year. Treatments were factorial combinations of OP (12 and 6 psi) and drip tape types (Tapes A, B, and $\mathrm{C}$ ) in a split-plot design, with each treatment replicated four times. $\mathrm{OP}$ was the main plot factor in randomized complete block design with tape as sub-plot factor. Before the dye test was performed, 28 -inch-wide raised beds were made, covered with low-density polyethylene mulch, and laid with drip tape on the surface. Each bed was divided into four plots of 20 -ft length for irrigation treatment for $45,90,180$, and $240 \mathrm{~min}$. Drip tapes between plots were connected by on/off valves. After pressurizing the system, $\approx 1$ gal of Brilliant blue CF dye (Terramark SPI High Concentrate; Prosource One, Memphis, TN) was injected at $1: 49$ (dye/ water) dilution rate for $\approx 30 \mathrm{~min}$ and the plots were subsequently irrigated. The plots with the shortest irrigation times were located farthest away from the water source (Fig. 2). At the end of each irrigation time, water flow was shut off for that plot. To keep the irrigation system water demand and pressure constant, one additional drip tape of equal length was opened every time when a section of drip tape was 


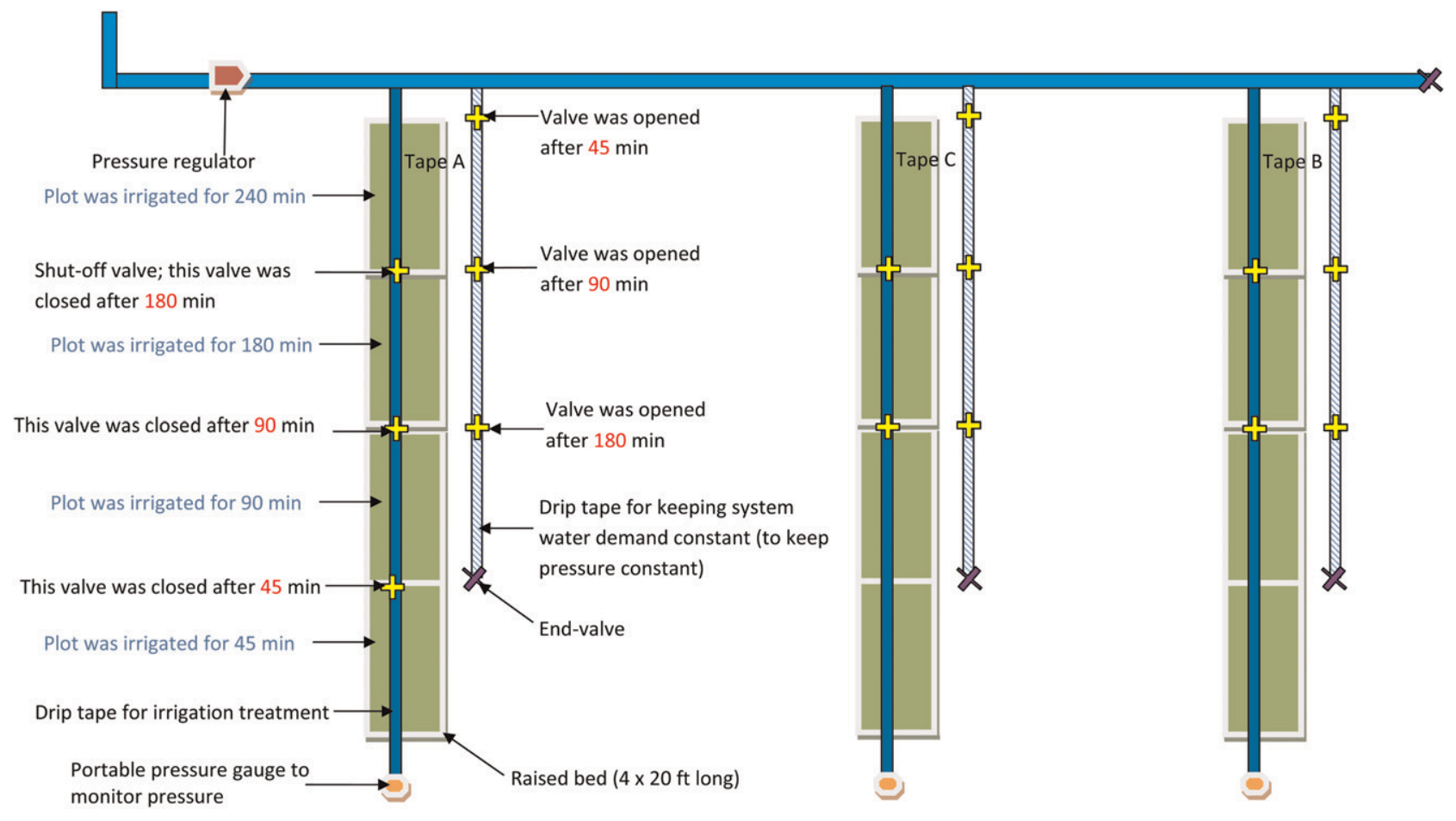

Fig. 2. Treatment plots in experiments conducted in Fall 2008 and 2009 in Florida, showing drip tape (solid line) with shutoff valves to create irrigation treatment durations of 45,90, 180, and $240 \mathrm{~min}$. An additional drip tape (striped line) with shut-off valves was used to keep the water demand and pressure constant by turning on a section of equal length as each section of the treatment tape was closed. $1 \mathrm{ft}=0.3048 \mathrm{~m}$.

turned off. Pressure was monitored at the end of the drip tape using a portable pressure gauge. Transverse sections of the beds on selected emitters were dug by hand after each irrigation time to observe the dye pattern, which was indicative of the wetted zone. Measurements of the maximum depth $[D$ (vertical length from the drip tape to the bottom of the blue dye) $]$ and width [ $W$ (maximum width of the blue dye)] of the dye pattern were taken. $D$ and $W$ responses to OP and drip tape type were analyzed using SAS Proc Mixed. As FRs for each OP and drip tape treatment were different, volumes of water applied would vary depending on the irrigation durations. Irrigated volumes $(V)$ were calculated for each treatment on the basis of FRs of each drip tape measured at 6 or 12 psi (as described in previous uniformity trials). Regression analysis of $D$ and $W$ responses to irrigated volume was carried out using SAS Proc REG. The square-root transformation of $V$ was used for comparison of intercepts and slopes between 6 and 12 psi treatments, which was analyzed with SAS Proc GLM to determine if the two regression lines were significantly different from one another (Milliken and Johnson, 2001).

\section{Results and discussion}

FRs AND UNIFORMITY. The measured pressure at the end of the drip tape averaged $5.5 \mathrm{psi}$ (range $=5-6 \mathrm{psi})$ and 10.5 psi ( range $=9-12$ psi) for the respective 6- and 12-psi OP treatments. Data from the two repetitions of the experiment were pooled as repetition $\times$ OP was not significant $\left(P=0.40\right.$ for FR, $P=0.99$ for $q_{\text {var }}, P=$ 0.91 for $\mathrm{Cv}$, and $P=0.86$ for $\mathrm{UC}$ ). Because tape $\times$ length interaction was significant $(P \leq 0.01)$, the variables FR, $q_{\text {var }}, \mathrm{CV}$, and UC were analyzed separately by drip tape. Measured FR more closely match theoretical ones for Tape A, whereas measured FRs were $10 \%$ to $25 \%$ lower for Tapes B and $\mathrm{C}$ at both 6 and 12 psi OP (Table l) compared with the theoretical FR, which could be attributed to different types of plastic materials used to manufacture the drip tapes. At 6 psi OP, FRs were reduced to $0.13,0.17$, and $0.16 \mathrm{gal} / \mathrm{h}$, decreases of $32 \%$, $23 \%$, and $38 \%$ compared with FRs at 12 psi, for Tapes A, B, and C $(P \leq$ 0.01 for all three tapes), respectively. This shows that FRs can be reduced by reducing $\mathrm{OP}$ and the FRs at reduced OP could be approximated from $k$ and $x$ values, which could be obtained from manufacturers. Flow rate was also significantly affected by drip tape length, with higher FRs of $0.17,0.20$, and $0.23 \mathrm{gal} / \mathrm{h}$ at $100 \mathrm{ft}$ compared with $0.15,0.18$, and 0.18 $\mathrm{gal} / \mathrm{h}$ at $300 \mathrm{ft}$ for Tapes $\mathrm{A}(P<0.01)$, $\mathrm{B}(P=0.02)$, and $\mathrm{C}(P<0.01)$, respectively.

Emitter flow variation $<10 \%$ may be regarded as "good" and $q_{\mathrm{var}}>20 \%$ as "unacceptable" (Safi et al., 2007). Coefficient of variation is classified as "excellent" at $<5 \%$ and unacceptable at $>15 \%$ (American Society of Agricultural Engineers, 1996). A UC of $>90 \%$ is considered as excellent and $<50 \%$ is unacceptable (Smajstrla et al., 2008). The uniformity parameters $q_{\mathrm{var}}, \mathrm{CV}$, and UC were not significantly affected by OP in all three drip tapes (Table 2). However, $q_{v a r}$ for Tape A was unacceptable at $23 \%$ at 6 psi compared with $10 \%$ at 12 psi. Tape B had good $q_{\mathrm{var}}$ of $9 \%$ at both 6 and 12 psi, whereas Tape C had "moderate" $q_{\text {var }}$ of $16 \%$ and $14 \%$ for 6 and 12 psi, respectively. A similar trend in $\mathrm{CV}$ was obtained for each drip tape, with Tape B showing excellent CV below 
Table 1. Theoretical and measured flow rates (FRs) for three drip tapes at 6 and 12 psi (41.4 and 82.7 kPa) operating pressure $(\mathrm{OP})$ and at two lengths of 100 and $300 \mathrm{ft}(30.5$ and $91.4 \mathrm{~m})$.

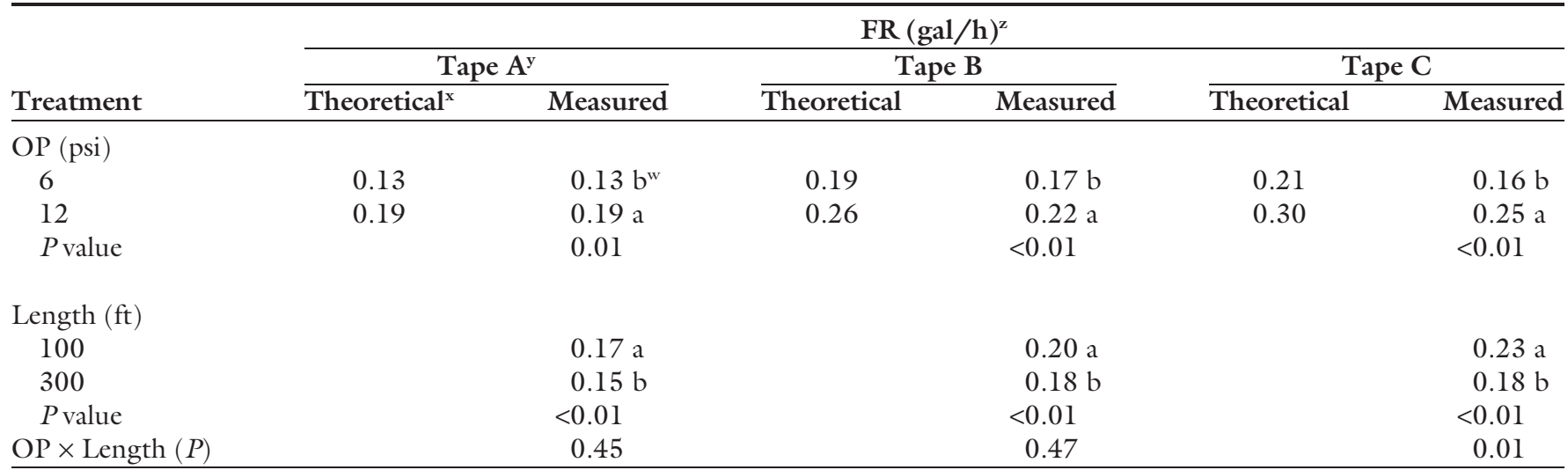

${ }^{2} \mathrm{lgal}=3.7854 \mathrm{~L}$.

'Tape A = Eurodrip, $0.16 \mathrm{gal} / \mathrm{h}$ at $10 \mathrm{psi}(68.9 \mathrm{kPa})$; Tape $\mathrm{B}=$ Typhoon, $0.24 \mathrm{gal} / \mathrm{h}$ at $10 \mathrm{psi}$; Tape $\mathrm{C}=\mathrm{Ro}-\mathrm{Drip}, 0.24 \mathrm{gal} / \mathrm{h}$ at $8 \mathrm{psi}(55.2 \mathrm{kPa})$.

${ }^{x}$ Theoretical FR calculated from flow equation $q=k p^{x}$, where $q$ is the emitter FR (gal $/ \mathrm{h}$ ), $p$ is the operating pressure (psi), $k$ is the emitter discharge coefficient, and $x$ is emitter discharge exponent. Tape A: $k=0.055, x=0.49$; Tape B: $k=0.084, x=0.45$; Tape C: $k=0.081, x=0.52$.

"Values are pooled data from two experiments conducted in Fall 2009 in Florida (repetition $\times$ factor: $P=0.40)$ and values with different letters within the same column are significantly different at $\alpha=0.05$ by pairwise comparison with least-squared means.

Table 2. Emitter flow variation ( $\left.q_{\mathrm{var}}\right)$, coefficient of variation (cv), and uniformity coefficient (UC) and their ratings (Rt) for three drip tapes at 6 and $12 \mathrm{psi}(41.4$ and $82.7 \mathrm{kPa})$ operating pressure $(\mathrm{OP})$ and at two lengths of 100 and $300 \mathrm{ft}(30.5$ and $91.4 \mathrm{~m})$.

\begin{tabular}{|c|c|c|c|c|c|c|c|c|c|c|c|c|c|c|c|c|c|c|}
\hline \multirow[b]{4}{*}{ Treatment } & \multicolumn{18}{|c|}{ Uniformity parameters } \\
\hline & \multicolumn{6}{|c|}{ Tape $A^{z}$} & \multicolumn{6}{|c|}{ Tape B } & \multicolumn{6}{|c|}{ Tape $\mathbf{C}$} \\
\hline & \multicolumn{2}{|c|}{$q_{\mathrm{var}}$} & \multicolumn{2}{|c|}{$\mathrm{CV}$} & \multicolumn{2}{|c|}{$\mathrm{UC}$} & \multicolumn{2}{|c|}{$q_{\mathrm{var}}$} & \multicolumn{2}{|c|}{$\mathrm{CV}$} & \multicolumn{2}{|c|}{ UC } & \multicolumn{2}{|c|}{$q_{\text {var }}$} & \multicolumn{2}{|c|}{$\mathrm{CV}$} & \multicolumn{2}{|c|}{$\mathrm{UC}$} \\
\hline & $(\%)$ & $\mathrm{Rt}^{\mathrm{y}}$ & $(\%)$ & $\mathbf{R t}$ & $(\%)$ & $\mathbf{R t}$ & $(\%)$ & $\mathbf{R t}$ & $(\%)$ & $\mathbf{R t}$ & $(\%)$ & $\mathbf{R t}$ & $(\%)$ & $\mathbf{R t}$ & $(\%)$ & $\mathbf{R t}$ & $(\%)$ & $\mathbf{R t}$ \\
\hline \multicolumn{19}{|l|}{$\mathrm{OP}(\mathrm{psi})$} \\
\hline 6 & 23 & $\mathrm{U}$ & 12 & M & 91 & $\mathrm{E}$ & 9 & G & 4 & $\mathrm{E}$ & 97 & $\mathrm{E}$ & 16 & M & 8 & M & 94 & $\mathrm{E}$ \\
\hline 12 & 10 & M & 5 & M & 97 & $\mathrm{E}$ & 9 & G & 4 & $\mathrm{E}$ & 97 & $\mathrm{E}$ & 14 & M & 7 & M & 95 & $\mathrm{E}$ \\
\hline \multicolumn{19}{|l|}{ Length (ft) } \\
\hline 100 & 15 & M & 10 & M & 93 & $\mathrm{E}$ & $5 \mathrm{~b}^{\mathrm{x}}$ & G & $3 \mathrm{~b}$ & $\mathrm{E}$ & $96 \mathrm{~b}$ & $\mathrm{E}$ & $9 \mathrm{~b}$ & G & $5 \mathrm{~b}$ & M & $96 \mathrm{~b}$ & $\mathrm{E}$ \\
\hline 300 & 18 & M & 8 & M & 95 & $\mathrm{E}$ & $13 \mathrm{a}$ & M & $5 \mathrm{a}$ & M & $98 \mathrm{a}$ & $\mathrm{E}$ & $22 \mathrm{a}$ & $\mathrm{U}$ & $9 \mathrm{a}$ & M & $93 \mathrm{a}$ & $\mathrm{E}$ \\
\hline$P$ value & 0.25 & & 0.30 & & 0.17 & & $<0.01$ & & 0.04 & & 0.06 & & $<0.01$ & & $<0.01$ & & $<0.01$ & \\
\hline OP $\times$ Length $(P)$ & 0.59 & & 0.21 & & 0.12 & & 0.11 & & 0.13 & & 0.15 & & 0.77 & & 0.74 & & 0.69 & \\
\hline
\end{tabular}

${ }^{2}$ Tape A = Eurodrip, $0.16 \mathrm{gal} / \mathrm{h}$ at $10 \mathrm{psi}(68.9 \mathrm{kPa})$, Tape $\mathrm{B}=$ Typhoon, $0.24 \mathrm{gal} / \mathrm{h}$ at $10 \mathrm{psi}$, and Tape C $=\mathrm{Ro}-\mathrm{Drip}, 0.24 \mathrm{gal} / \mathrm{h}$ at $8 \mathrm{psi}(55.2 \mathrm{kPa})$.

${ }^{y} q_{\text {var }}: \mathrm{G}=\operatorname{good}(<10 \%), \mathrm{M}=$ moderate $(10 \%$ to $20 \%), \mathrm{U}=$ unacceptable $(>20 \%) ; \mathrm{cv}: \mathrm{E}=$ excellent $(<5 \%), \mathrm{M}=\operatorname{moderate}(5 \%$ to $15 \%), \mathrm{U}=$ unacceptable $(>15 \%) ; \mathrm{UC}: \mathrm{E}=\mathrm{excellent}$ $(>90 \%), \mathrm{U}=$ unacceptable $(<50 \%)$

${ }^{x}$ Values are obtained from pooled data of two experiments conducted in Fall 2009 in Florida (repetition $\times$ factor: $P=0.99$ for $q$ var, $P=0.91$ for $\mathrm{CV}$, and $P=0.86$ for UC) and values with different letters within the same column are significantly different at $\alpha=0.05$ by pairwise comparison with least-squared means

5\%. However, all three tapes showed excellent UC greater than $90 \%$. These results show that reducing the system OP did not practically reduce the uniformity of water application, although certain drip tape type may show greater variations in emitter flow.

Tape length had a significant effect on the uniformity of Tapes $B$ and $\mathrm{C}$, but not on that of Tape A. Longer runs of Tapes B and $\mathrm{C}$ showed greater $q_{\text {var }}(13 \%$ and $22 \%$ for Tapes B and C, respectively; $P<0.01$ for both) and greater CV $[5 \%$ and $9 \%$ for Tapes B $(P=0.03)$ and $\mathrm{C}(P<0.01)$, respectively] compared with short runs ( $q_{\text {var }}$ of $5 \%$ and $9 \%$ for Tapes $B$ and C, respectively, and $\mathrm{CV}$ of $3 \%$ and $5 \%$ for Tapes $\mathrm{B}$ and $\mathrm{C}$, respectively) (Table $2)$. The $q_{\text {var }}$ for Tape B at $300 \mathrm{ft}$ was "moderate," whereas qvar for Tape C at $300 \mathrm{ft}$ was "unacceptable," although CV for both tapes was "moderate." On the basis of these results, reduced OP seems to be more appropriate for short runs as they allow for greater uniformity. Poor uniformity of water application and unevenly distributed water would create zones of over/under irrigations and reduction in crop growth uniformity, leading to potential yield reductions and excessive nutrient leaching (Dukes et al.,
2010). This makes reduced OP a practice better suited for small fields or for large fields with multiple zones and short rows.

Although reducing OP significantly reduced FRs [from 0.13 to $0.17 \mathrm{gal} / \mathrm{h}$ at $6 \mathrm{psi}$ (Table 1$)]$ without affecting uniformity of irrigation, the FRs obtained were comparable to currently available drip tapes with low FR of $0.15 \mathrm{gal} / \mathrm{h}$. Therefore, to apply water to more closely match hourly water needs in a sandy soil and reduce the risk of deep percolation, currently available low flow drip tape could be used. However, having a drip tape at a higher FR of $0.24 \mathrm{gal} / \mathrm{h}$ offers more 
versatility to the grower. By installing an adjustable in-line pressure regulator, he/she could reduce the FRs to match the periods of low ETc and revert to high FRs during maximum ETc. It is important for the grower to select the right type of drip tape that would have low variation at reduced OP. To do so, it would be helpful if manufacturers could provide expected FRs and information on other uniformity parameters such as $q_{\mathrm{var}}$ and CV at reduced OP on the drip tape label so that growers could make an informed decision on whether the drip tape is suitable to be used in a system with reduced OP.

MOVEMENT OF WATERFRONT. The dye pattern appeared as a round to elliptical blue ring surrounding an uncolored section of soil as clear water was injected after the dye (Fig. $3)$. This pattern was similar to those reported in this and other sandy soils of Florida (Farneselli et al., 2008; Simonne et al., 2003, 2005, 2006a; Zotarelli and Dukes, 2010). Because, year $\times$ OP and tape $\times$ OP interactions were not significant for $D(P=0.26$ and 0.06 , respectively $)$ and $W(P=$ 0.05 and 0.36 , respectively), responses to irrigated volume were pooled for

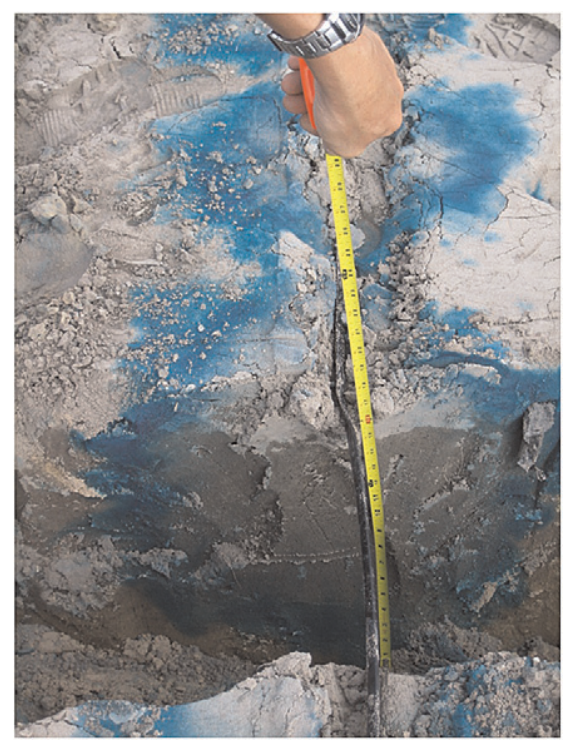

Fig. 3. Transverse section of an AlpinBlanton-Foxworth sandy soil beneath one emitter showing elliptical dye pattern after irrigating for $4 \mathrm{~h}$ at $12 \mathrm{psi}$ $(82.7 \mathrm{kPa})$ using drip tape of $24 \mathrm{gal} /$ $100 \mathrm{ft}\left(2.98 \mathrm{~L} \cdot \mathrm{m}^{-1}\right)$ per hour, 12 -inch $(30.5 \mathrm{~cm})$ emitter spacing. Note that the water front reached the 17 -inch $(43.2 \mathrm{~cm})$ depth. both years and all drip tapes. Depth response to volume of irrigated water was quadratic and described as $D=$ $5.34+0.16 V-0.0007 V^{2}(P<0.01$, $\left.R^{2}=0.80\right)$ at 12 psi and $D=4.42+$ $0.21 \mathrm{~V}-0.001 \mathrm{~V}^{2}\left(P<0.01, R^{2}=\right.$ 0.72 ) at 6 psi (Fig. $4 \mathrm{~A})$. The intercepts and slopes for the transformed regression lines were not significantly different $(P=0.37$ and 0.60 , respectively), which indicated that depth response to volume was unaffected by OP. The depth of wetted zone was beyond the active crop root zone of 12 inches when $V$ was $\approx 45 \mathrm{gal} /$ $100 \mathrm{ft}$, which represented $\approx 3 \mathrm{~h}$ of irrigation at 6 psi and $1.8 \mathrm{~h}$ of irrigation at 12 psi for a typical drip tape with FR of $24 \mathrm{gal} / 100 \mathrm{ft}$ per hour (Tape C). These results show that, for the same volume of water applied, reduced OP allowed extended irrigation without increasing the wetted depth.

The width of the wetted front also showed a quadratic response to irrigated volume and could be described as $W=7.58+0.17 \mathrm{~V}-$ $0.0006 V^{2}\left(P<0.01, R^{2}=0.77\right)$ at $12 \mathrm{psi}$ and $W=6.97+0.25 \mathrm{~V}-$ $0.002 V^{2}\left(P<0.01, R^{2}=0.70\right)$ at 6 psi (Fig. 4B). The intercepts and
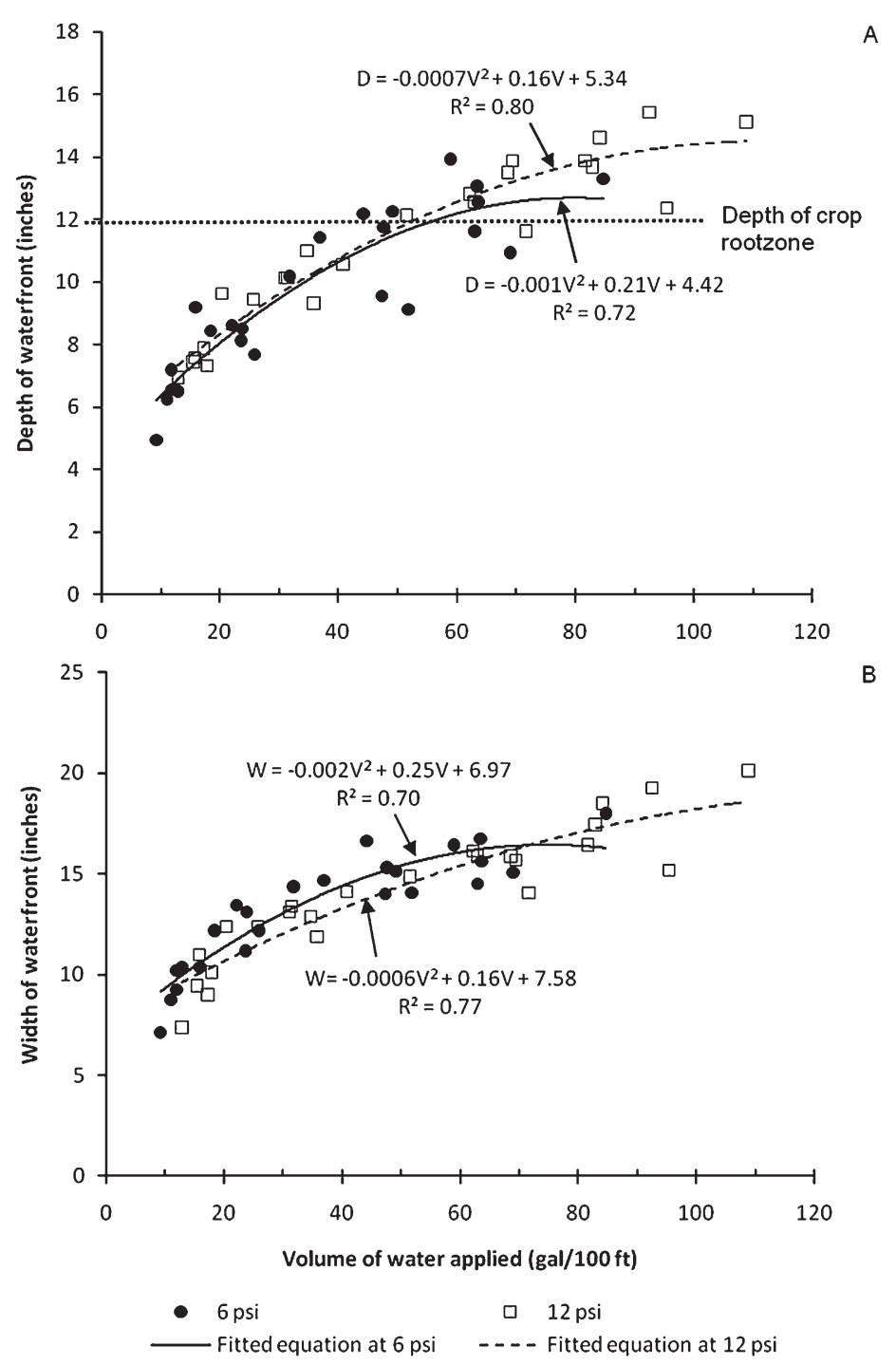

Fig. 4. Effect of irrigation volume $(V)$ on $(A)$ depth $(D)$ and $(B)$ width $(W)$ of wetted zone at operating pressure (OP) of 6 and $12 \mathrm{psi}(41.4$ and $82.7 \mathrm{kPa})$ on an Alpin-Blanton-Foxworth sandy soil using selected drip tapes [12-inch $(30.5 \mathrm{~cm})$ emitter spacing] in Fall 2008 and 2009, Florida. Data were pooled from 2 years [year $\times \mathrm{OP}$ and tape $\times \mathrm{OP}$ interactions were not significant for $D(P=0.26$ and 0.06 , respectively) and $W(P=0.05$ and 0.36 , respectively $)] .1 \mathrm{psi}=6.8948 \mathrm{kPa}$, $1 \mathrm{gal} / 100 \mathrm{ft}=0.1242 \mathrm{~L} \cdot \mathrm{m}^{-1}$, and $1 \mathrm{inch}=2.54 \mathrm{~cm}$. 
slopes of the transformed lines were not significantly different $(P=0.37$ and 0.94 , respectively), which indicates that OP did not affect the width of the wetted zone. For a fixed $V$ within the tested range of 9-108 gal/ $100 \mathrm{ft}$, the increase in wetted width at 6 psi was not significant compared with that at 12 psi. However, maximum $W$ of 14.8 inches was reached at a lower $V(V=62.5 \mathrm{gal} / 100 \mathrm{ft})$ for the 6 psi treatment, which accounted for $53 \%$ of the 28 -inch-wide bed. At 12 psi, maximum $W$ of 19.6 inches ( $70 \%$ of bed width) was predicted at $V=142 \mathrm{gal} / 100 \mathrm{ft}$. Previous studies have reported wetted bed width of $57 \%$ to $70 \%$ when irrigation was applied at 10 to 12 psi (Santos et al., 2003; Simonne et al., 2006a). These results suggest that reduced OP is more suited for crops planted in single-row arrangements if a single drip tape was used because if there were two rows of plants, there may not be sufficient lateral movement of water to irrigate plants at the sides of the bed. Additionally, if reduced OP was used for drip-injected soil fumigants, it would be necessary to use two drip tapes to ensure good coverage and uniform application of the fumigant as was suggested by Csinos et al. (2001), who found maximum wetted bed width of $60 \%$ for a 25 -inch-wide bed. For irrigation scheduling purposes, using a low OP of 6 psi can wet $\approx 7.5$ inches on either side of the drip tape, and with complete emitterto-emitter coverage of 12 inches estimated to be at $\mathrm{V}=25 \mathrm{gal} / 100 \mathrm{ft}$ $(\approx 1.5 \mathrm{~h}$ of irrigation). These results showed that for a given irrigated volume, reduced OP did not decrease the depth nor increase the width of the wetted zone. Instead, the actual volume of irrigated water applied is more important in determining movement of the waterfront.

\section{Conclusion}

With the use of reduced OP (6 psi), FR for the three selected drip tapes was significantly reduced by $23 \%$ to $38 \%$ depending on the type of drip tape. Short runs $(100 \mathrm{ft}$ ) of drip tapes were more uniform than long runs $(300 \mathrm{ft})$, although it also depends on the drip tape type. Reduced OP is more appropriate for short runs as they allow for greater uniformity, making reduced OP more suited for small fields or for large fields with multiple zones of short rows. It is important to select a suitable drip tape that has low variation and high uniformity in water application. Reduced OP neither decreases the depth of the waterfront in the soil nor affects the wetted width for a given irrigated volume applied. The crop root zone depth of 12 inches was attained after $3 \mathrm{~h}$ of irrigation at 6 psi compared with $1.8 \mathrm{~h}$ at $12 \mathrm{psi}$, indicating that reduced OP allows extended irrigation without moving the waterfront downward. Maximum wetted bed width at reduced OP was $\approx 53 \%$ of bed width, which makes reduced OP more suited for single-row plant crops if only a single drip tape was used. Reduced OP offers growers a simple method to reduce FR so that irrigation water could be applied at rates that match more closely the hourly ET to minimize deep water percolation and subsequent leaching losses. Growers could make better choices of drip tape if manufacturers provided information on FRs, emitter variation, and uniformity at different $\mathrm{OP}$ on the drip tape labels.

\section{Literature cited}

American Society of Agricultural Engineers. 1996. Field evaluation of microirrigation systems. EP405.1. ASAE Standards. Amer. Soc. Agr. Eng., St. Joseph, MI.

Badr, M.A. and A.S. Taalab. 2007. Effect of drip irrigation and discharge rate on water and solute dynamics in sandy soil and tomato yield. Austral. J. Basic Appl. Sci. 1:545-552.

Bar-Yosef, B. and M.R. Sheikolslami. 1976. Distribution of water and ions in soils irrigated and fertilized from a trickle source. Proc. Soil Sci. Soc. Amer. 40:575-582.

Camp, R.C., E.J. Sadler, and W.J. Busscher. 1997. A comparison of uniformity measures for drip irrigation systems. Trans. Amer. Soc. Agr. Eng. 40:10131020 .

Clark, G.A. and A.G. Smajstrla. 1996. Design considerations for vegetable crop drip irrigation systems. HortTechnology $6: 155-159$.

Csinos, A., J.E. Laska, K. Seebold, and J. Eger. 2001. Evaluation of microirrigation wetting patterns in polyethylene film mulch beds. 22 Aug. 2010. <http:// mbao.org/200lproc/047\%20Eger\%20J\% 20evaluationof $\% 20$ microirrigationaug 2001 . pdf>.

Dowgert, D., B. Marsh, R. Hutmacher, D. Hannaford, J. Phene, and C. Phene.
2007. Low pressure drip irrigation lessens agricultural inputs. 22 Jan. 2010 . <http:// www.icwt.net/conference/Irrigation/ Session\%20E/Michael\%20D.pdf>.

Dukes, M.D., L. Zotarelli, and K.T. Morgan. 2010. Use of irrigation technologies for vegetable crops in Florida. HortTechnology 20:133-142.

Farneselli, M., D.W. Studstill, E.H. Simonne, R.C. Hochmuth, G.J. Hochmuth, and F. Tei. 2008. Depth and width of the wetted zone in a sandy soil after leaching drip-irrigation events and implications for nitrate-load calculation. Commun. Soil Sci. Plant Anal. 39:1183-1192.

Florida Department of Agriculture and Consumer Services. 2005. Water quality/quantity best management practices for Florida vegetable and agronomic crops. 10 May 2010. <http://www.floridaagwaterpolicy. com/PDF/Bmps/Bmp_VeggieAgroCrops 2005.pdf>.

Hammami, M. and H. Daghari. 2007. Tomato roots distribution and water uptake: Contribution for trickle irrigation management. Acta Hort. 758:227-233.

Levin, L., P.C. van Rooyen, and F.C. van Rooyen. 1979. The effect of discharge rate and intermittent water application by point-source irrigation on the soil moisture distribution pattern. Soil Sci. Soc. Amer. J. 43:8-16.

Machado, R.M.A., M. do Rosário, G. Oliveira, and A.M. Portas. 2003. Tomato root distribution, yield and fruit quality under subsurface drip irrigation. Plant Soil 255:333-341.

Milliken, G.A. and D.E. Johnson. 2001. Analysis of messy data, Vol. 3: Analysis of covariance. CRC Press, Boca Raton, FL.

Mmolawa, K. and D. Or. 2000. Root zone solute dynamics under drip irrigation: A review. Plant Soil 222:163-190.

Obreza, T.A. and J.B. Sartain. 2010. Improving nitrogen and phosphorus fertilizer use efficiency for Florida's horticultural crops. HortTechnology 20:23-33.

Safi, B., M.R. Neyshabouri, A.M. Nazemi, S. Massiha, and S.M. Mirlatifi. 2007. Water application uniformity of a subsurface drip irrigation system at various operating pressures and tape lengths. Turk. J. Agr. For. 31:275-285.

Santos, B.M., J.P. Gilreath, and T.N. Motis. 2003. Length of irrigation and soil humidity as basis for delivering fumigants through drip lines in Florida spodosols. Proc. Florida State Hort. Soc. 116:85-87.

Simonne, E., D. Studstill, and R.C. Hochmuth. 2006a. Understanding water movement in mulched beds on sandy soils: An approach to ecologically sound 
fertigation in vegetable production. Acta Hort. 700:173-178.

Simonne, E., M. Dukes, G. Hochmuth, B. Hochmuth, and D. Studstill. 2006b. Monitoring nitrate concentration in shallow ground water below a vegetable field. Proc. Florida State Hort. Soc. 119:226230.

Simonne, E.H., D.W. Studstill, R.C. Hochmuth, G. McAvoy, M.D. Dukes, and S.M. Olson. 2003. Visualization of water movement in mulched beds with injections of dye with drip irrigation. Proc. Florida State Hort. Soc. 116:88-91.

Simonne, E.H., D.W. Studstill, R.C. Hochmuth, J.T. Jones, and C.W. Starling. 2005. On-farm demonstration of soil water movement in vegetables grown with plasticulture. 22 Jan. 2010. <http://edis. ifas.ufl.edu/HS25l>.

Simonne, E.H., M.D. Dukes, and L. Zotarelli. 2010. Principles and practices of irrigation management for vegetables, p. 17-27. In: S.M. Olson and B. Santos (eds.). Vegetable production handbook for Florida 2010-2011. Vance Publishing, Lenexa, KS.

Smajstrla, A.G., B.J. Boman, D.Z. Haman, D.J. Pitts, and F.S. Zazueta. 2008. Field evaluation of mircoirrigation water application uniformity. 12 Jan. 2009. <http:// edis.ifas.ufl.edu/ae094>.

Thompson, A.L. 2003. Drip irrigation, p. 206-210. In: D.R. Heldman (ed.). Encyclopedia of agricultural, food and biological engineering. Marcel Dekker, New York.
University of Florida. 2010. Florida Automated Weather Network (FAWN). 11 Sept. 2010. <http://fawn.ifas.ufl.edu>.

U.S. Department of Agriculture. 2006. Soil survey of Suwannee County, Florida. 22 Jan. 2010. <http://nrcs.usda.gov>.

Zotarelli, L. and M.D. Dukes. 2010. Evaluation and demonstration of soil moisture based on demand irrigation controllers for vegetable production. 16 Sept. 2010. <http://www.swfwmd.state. fl.us/files/database/site_file_sets/42/ Soil-Sensors-SWFWMD_B228-FinalReport_03302010.pdf>.

Zur, B. and J.W. Jones. 1981. A model for the water relations, photosynthesis, and expansive growth of crops. Water Resoures Res. 17:311-320. 